\title{
電池鼻腔内異物（ボタン型アルカリ電池）の一症例 およびその局所傷害に関する実験的研究
}

\author{
日本医科大学耳鼻咽喉科学教室（主任：八木聰明教授） \\ 大 橋 普吾, 服部康夫, 鶴 窪 - 行, 中䳋 慶 則, 柏 戸 泉
}

CASE REPORT OF A FOREIGN BODY IN THE NASAL CAVITY : EXPERIMENTAL RESEARCH ON LIMITED DAMAGE

\section{SHINGO OHHASHI, M.D., YASUO HATTORI, M.D., KAZUYUKI TSURUKUBO, M.D. YOSHINORI NAKAJIMA, M.D. and IZUMI KASHIWADO, M.D.}

Department of Otolaryngology, Nippon Medical School, Tokyo

We report here a case of serious nasal cavity tissue damage caused by a foreign substance, specifically, a button-shaped battery.

The patient was a three-year-old boy who inserted a button-shaped battery into his left nasal cavity. On examination, we found necrosis of the nasal mucosa, cartilage and bone. In addition, the nasal cavity structure was severely damaged. In a follow-up experiment, we inserted a similar button -shaped battery, pre-soaked in a salt solution, into a rabbit's nasal cavity and measured daily changes in $\mathrm{PH}$ and discharge over time. In addition, we assesed how much nasal cavity tissue was damaged in a pathological specimen.

We found that the chief factor mediating tissue damage, among those we tried, was strong base production with lowvoltage discharge. Under these conditions the nasal cavity is damaged in a short time.

Key words : 鼻腔内異物, ボタン型電池, 鼻中隔穿孔, 強アルカリ $\quad$ A96-0387-32781

はじめに

ボタン型アルカリ電池は近年, カメラ, 電卓や電子 ゲーム等に多用され，日常容易に幼児の手の届くもの になっている.この電池の形状は円形で, 直径は $11 \mathrm{~mm}$ 前後, 厚さは $4 \mathrm{~mm}$ 前後と異物となるには好都合な大 きさである。その内容は重金属と強アルカり波であり， これが異物となって内容波が漏出したり, 低電圧放電 が起こ机ば重大な組織鹪害を起こす可能性がある.

今回，我々はボタン型電池により重大な組織傷害を 起こした幼児の㐭腔内異物の一症例を経験したので, 若干の文献的考察を行うとともに，局所傷害に関する 動物実験を行ったので，その知見に若干の文献的考察 などを加えて報告する。
患 者：3歳, 男児

I 症例

初診: 1989年11月 4 日

主 訴: 左血性鼻漏, 左頝部発赤腫脹

家族歷・既往歴：特記すべきことなし

現病歴：初診 3 日前の1989年11月 1 日に母親が患者 の主訴に気づいたが，そのまま放置していた。11月 4

日, 主訴が増恶したため某医院を受診し, 左鼻腔内の ボタン型電池を摘出された(図 1)。このボタン型電池 は父親がカメラ用に購入しておいたもので，新品のま

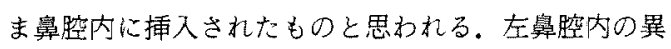
常所見と左㛲部に強い炎症所見䘮認妉ため, 同日当 科を紹介され受診した。 


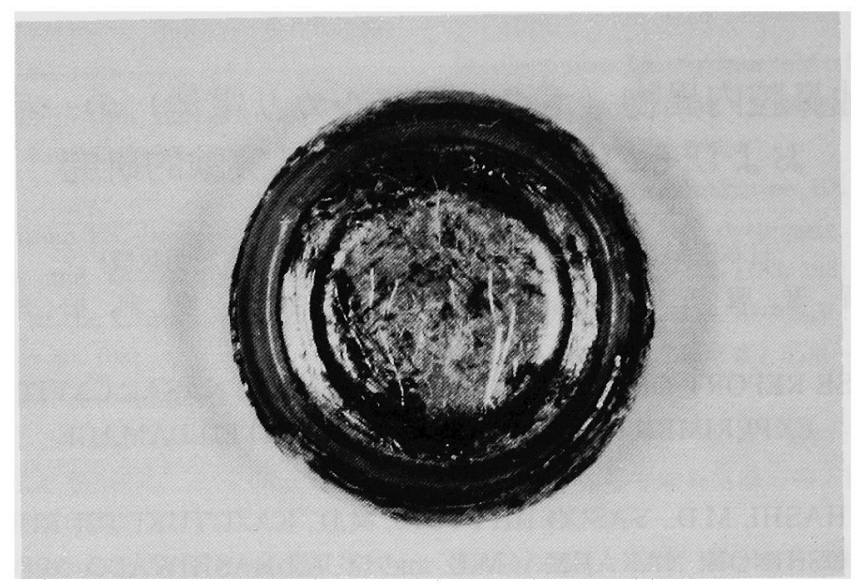

図 1 摘出されたボタン型電池

現症及び経過：初診時, $37.5^{\circ} \mathrm{C}$ 発熱と左煩部の発 赤, 腫脹及び同部の疼痛を認めた。左鼻腔全体が暗褐 色の痂皮に被われ，一部より出血を認めた。中甲介， 下甲介は壊死状態で，鼻中隔軟骨が露出していた （図 2 ）。血液検查にて，白血球数； $24,400 / \mathrm{mm}^{3}$, $\mathrm{CRP} ; 11.5 \mathrm{mg} / \mathrm{dl}$ ，血沈； 1 時間値 $25 \mathrm{~mm}, 2$ 時間値 $82 \mathrm{~mm}$ であった．X線所見では後頭前頭位単純撮影お よびWaters 法 (図 3) にて左上枵洞内に霉漫性の陰影 が認められた。即日入院の上, 全身麻酔下に蒸留水に て鼻腔を洗浄し，壊死組織の除去を試みた，入院中， 抗生物質，消炎鎮痛剂，消炎醅素剂，抗ヒス夕ミン剂 などを投与した。11月 9 日，壊死状態に著変はなかっ たが, 白血球数; $8,200 / \mathrm{mm}^{3}, \mathrm{CRP} ; 1.9 \mathrm{mg} / \mathrm{dl}$, 血沈; 1 時間值 $8 \mathrm{~mm}, 2$ 時間値 $12 \mathrm{~mm}$ となり, 左煩部の発 赤，腫脹も消退したので退院した。退院後 2 力月を経 過してもなお，鼻腔の壊死状態は改善せず易出血性で あり，鼻中隔穿孔を来した。

摘出された電池を株式会社ソニー・エナジー・テッ クの品質技術部に依頼し分析したところ, 以下の結果 が得られた。

1）電池の種類はボタン型アルカリ マンガン電池 で, 未使用の電池では直径 $11.6 \mathrm{~mm}$, 厚さ $4.2 \mathrm{~mm}$, 重 量 $1.5 \mathrm{~g}$, 起電力 $1.5 \mathrm{v}$, 電気容量 $104 \mathrm{mAH}$ の規格のも のであった。また，その構造は図 4 に示すごと々，軟 銅をニッケルメッキした正極カプセルの中に正極合剤 の $\mathrm{MnO}_{2}$ と負極要鉛が満たされ，その間に $45 \%$ の水酸 化カリウム $50 \mathrm{mg}$ を浸したフェルトが置かれている.

2) 摘出された電池の残存起電力は $0.17 \mathrm{~V}$, 重量は

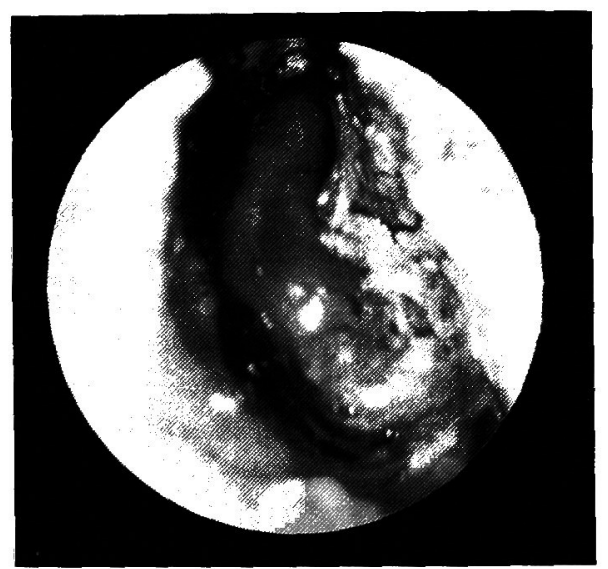

図 2 初診時の鼻腔内写真

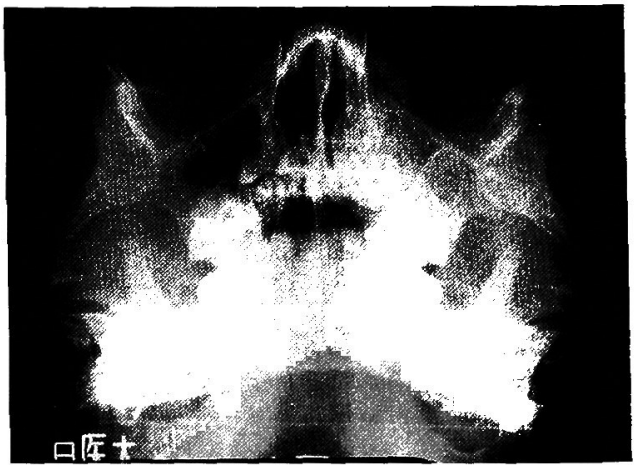

図 3 初診時の後頭前頭位単純撮影 


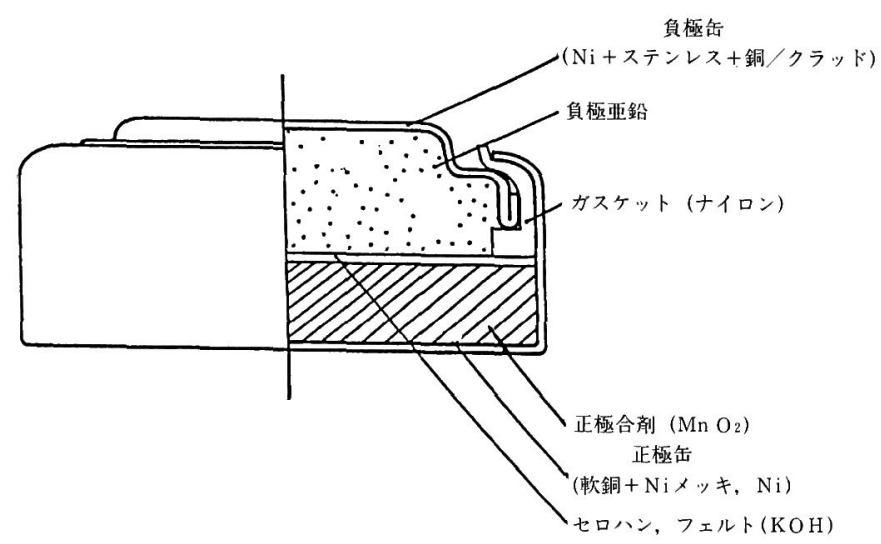

図 4 ボタン型電池の内部構造

\subsection{5g であった.（図 5 )}

3）電池表面の大部分は腐食していたが, 穿孔は確 認し得なかった。

4）電池表面腐食部分の $\mathrm{X}$ 線マイクロアナライザー 分析によりカリウムが検出された（図 5 ).

\section{II 実験的研究}

1. ボタン型アルカリマンガン電池の生理食塩水中 における放電実験

同型電池を生理食塩水中に置いた場合, 放電により どのような変化が起こるか, 完全に放電するにはどれ くらいの時間を要するのかを知るために，以下の実験 を行った。

方法：異物と同型の電池（SONY 製 LR43）を生理 食塩水 $100 \mathrm{ml}$ 中に浸し, 経時的, 経日的に以下の項目 につき観察した. 1) 電池の起電力の変化を電圧計 (HIOKI製 Hi TESTER MODEL3000) を用いて測

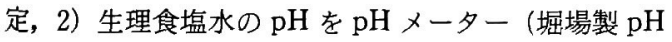
Analyzer F-80）を用いて測定，3）20日後の生理食塩 水を 1 規定塩酸を用いて滴定した.

結果：起電力と $\mathrm{pH}$ の経時的および経日的変化を 図 6 に示した。起電力は初め急速に低下し 3 日後に $0.7 \mathrm{~V}$ となり,その後は徐々に低下し, 10 日には $0.25 \mathrm{~V}$, 15 日後には $0.15 \mathrm{~V}$ となり平行状態(これ以上放電しな い状態）となった。

$\mathrm{pH}$ の值は電池投入前の 6.3 加ら急速に上昇し， 2 日 後には10.5, 3 日後も10.5であったが，その後徐々に 低下し20日後には9.5となった。

20 日後の生理食塩水 $100 \mathrm{ml}$ を 1 規定塩酸を用いて

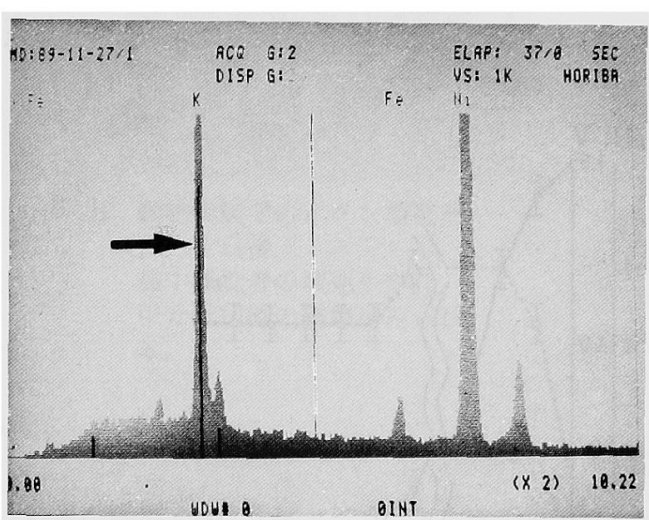

図 5 摘出電池のX線マイクロアナライザーによ る分析

電池表面に通常存在しないカリウムが増大 している $(\Rightarrow)$

中和滴定したところ $3.6 \mathrm{ml}$ を要した.

2. 家鬼鼻腔内に扔ける電池放電実験

同型のボタン型電池 (SONY 製 LR43型) を家鬼の 鼻腔内に挿入して, 電池の放電状況, 強アルカリの発 生状況，および鼻腔組織の壞死性変化を経時的，経日 的に 7 日まで観察した。

方法：未放電の電池を鼻入口部から $2 \mathrm{~cm}$ の総鼻道 まで挿入した後, 経時的, 経日的に 3 羽ずつ合計 21 羽 屠殺して, 1) 電池の起電力の変化を, 電流計 (HIOKI 製 Hi TESTER MODEL3000) を用いて測定した。 2) 鼻汁の $\mathrm{pH}$ を $\mathrm{pH}$ 試験紙（Whatman $\mathrm{pH}$ INDICATOR PAPER)により測定した. 3）鼻腔構造の壊死変 化を病理組織学的に観察した。 


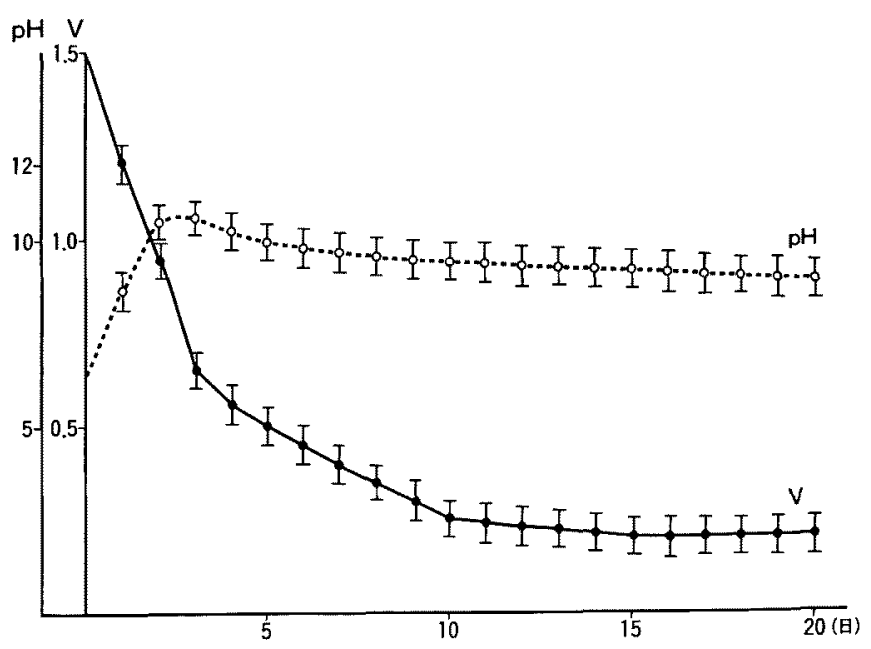

図 6 生理食塩水中での電池の放電実検

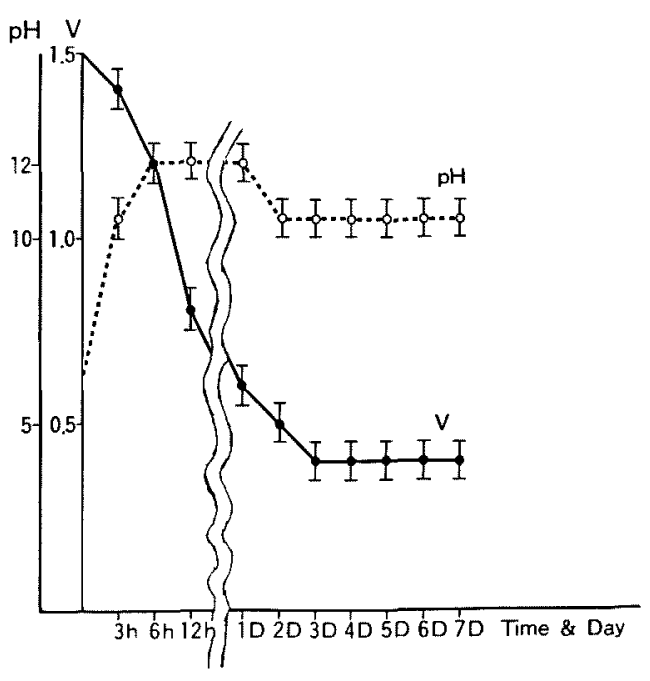

图 7 家鬼鼻整内での電池放電実験

結果：電池の起電力と舅汁の $\mathrm{pH}$ の推移を図 7 に示 した. 起電力は 12 時間後に $0.8 \mathrm{~V}, 1$ 日後に $0.6 \mathrm{~V}, 3$ 日後に $0.4 \mathrm{~V}$ にまで減少し以後平行状態となった。 $\mathrm{pH}$ は 3 時間後に10.5，6 時間後に11.5に上昇し, 極めて 短時間で強アルカリ性に変化した。．2日後には 10.5 に 低下し，そのまま7日後まで10.5であった，組織標本 では，無処置対照の鼻空（図 8 の）では，中央に鼻 中隔を認め, 甲介が複雑に発達している。実験群では 3 時間という短時間内に電池挿入側の上皮は剥離, 脱
落して，びらんを来し，間質にはリンパ球，好中球な どの炎症性細胞浸潤, 浮腫性及び出血性変化も見られ た.この変化は時間を追って増強し，1日後（図8の b ）には鼻中隔軟骨の壊死や穿孔，甲介骨組織の破壊 が見られた。 2 日後には反対側の甲介骨組織の破壊が 出現し，炎症細胞浸潤や鼻粘膜の壊死が見られた。 7 日後には鼻中隔はもちろん両側の甲介骨組織のはほと んぞが壊死されていた。

\section{III 考按}

ここ十数年来, 電子機器の発達によりボタン型アル カリ電池が多用されている。ボタン型電池にはアルカ リ・マンガン電池, 酸化銀電池, 水銀電池, ニッケル 電池とアルカリ空気電池などがある。これらはいずれ も円形で, 大きさは直径 8-16mm, 厚さ $2-6 \mathrm{~mm}$ と, 小 児にとって異物となるのに手ごろな形と大きさであ る.耳鼻咽喉科領域での報告は現在のところ多くな $\left(^{2) \sim 7}\right.$.この内, 鼻腔内異物症例は我々の調へた範囲で は，国内での報告が 7 症例あった(表 1 )。本症例を含 めて全例が小児であったの恃徵的である. 主訴のほ とんどは血性・澧性鼻漏で，これは鼻腔内異物にしば しば見られる症状であるが,ボタン型電池ではさらに， 疼痛を伴い, 规部腫脹を来し, 発熱を伴う場合もあり, 傷害の程度が大で, 重大な感染を疑わせる症状を呈す ることが特徵である，鼻腔粘膜は壊死に陥り鼻腔構造 は破壊され，鼻中隔穿孔や前鼻孔の閉銷を最終的に来 した症例がほとんどで, 電池の介在 4 時間で鼻中隔穿 


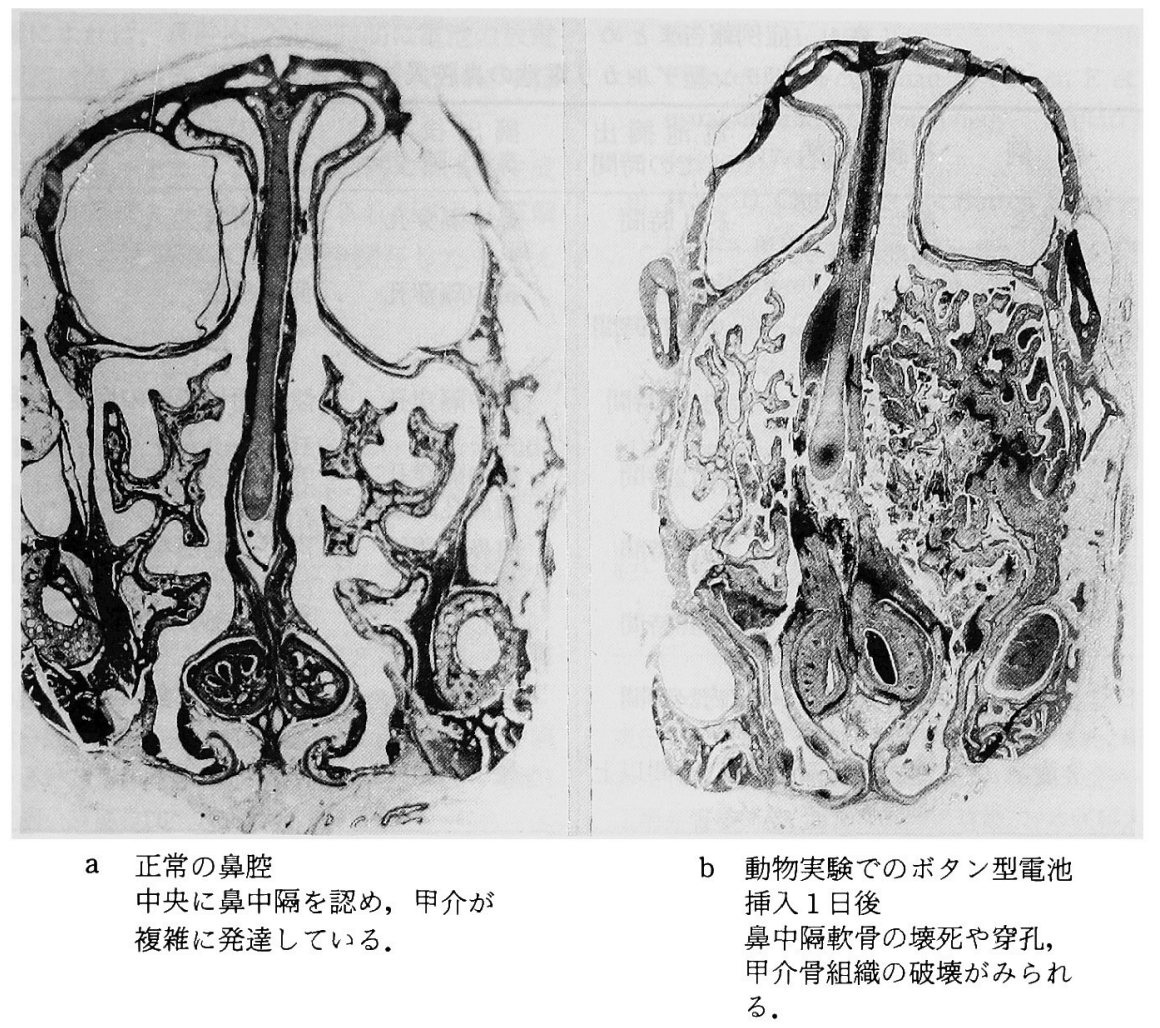

図 8 組織標本

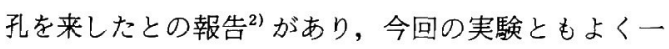
致し，極めて危険な異物であると言える，異物となっ たボタン型電池が組織傷害を起こす機序としては, 一 般に以下のことが言われている1)121.

（1）電池内の強アルカリが漏出し，これが組織傷 害を起こす。

（2）生体内で組織に低電圧の直流が流れると生体 内にある塩化ナトリウムは電気分解され, 陰極付近に 強アルカリを生じ，これが組織傷害を起こす5).

（3）電流が導体と導体の間に生じさせるアークな いしスパークにより発生する爆発力, 振盪作用, 高温 による電流斑によって組織傷害を起こす.

（4）電池そのものによる圧迫で循環傷害を来し, 組織傷害を起こす。（1）（2）の場合強アルカリは蛋 白と結合し, 直接的に組織を傷害するが, この時形成 された protenate が脂肪と結合して石鹼となり，この 石嘘と接触した組織がさらに傷害され, 進行性の組織 傷害を引き起こすと言われている ${ }^{12)}$.
我々の症例では，X線マイクロアナライザーにより カリウムが検出され電池重量の減少があったこと, さ らに電池の解体によって水酸化カリウム全量 $(50 \mathrm{mg})$ の漏出が証明された。また漏出部位は金属部分に穿孔 がなかったことより絶緑体部分と思われ, 電池摘出時 に漏出したと考えられる.

電池の放電によって, 強アルカリが生成されること は, 今回の実験結果から見ても明らかである、生理食 塩水中および家鬼鼻腔内の放電実験では，両者ともに 放電は初めの 1 日間で急速に進み, $\mathrm{pH}$ も初めの 1 日 間に急速に上舁し，高値のまま数日間持続した。生理 食塩中では山下ら5 の報告のように，陰極側に水酸化 ナトリウムが生じ $\mathrm{pH}$ が上昇したと考えられる.また, 生理食塩中では気体が発生したが，塩素及び水素と考 えられる，家兔の鼻腔内では放電の速さも $\mathrm{pH}$ の上昇 も生理食塩中より速やかであったが, これは体温によ り電流值が増大したことによると考えられる。また 各々の実験で $\mathrm{pH}$ が増加した後わずかながら徐々に低 
表 1 症例報告まとめ

ボタン型アルカり電池の鼻腔異物報告例

\begin{tabular}{|c|c|c|c|c|c|}
\hline 報告者 & 症 例 & 初診時症状 & $\begin{array}{l}\text { 電池摘出 } \\
\text { までの時間 }\end{array}$ & $\begin{array}{l}\text { 楛出後の } \\
\text { 鼻腔障吉 }\end{array}$ & 電 池 の 状 態 \\
\hline $\begin{array}{l}\text { 松本 } \\
(1976)\end{array}$ & 4 歳早 & 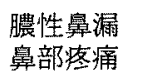 & 約 4 時間 & 鼻中隔穿孔 & 表面腐食 \\
\hline $\begin{array}{l}\text { 鈴木ら } \\
(1979)\end{array}$ & 4 歳兯 & $\begin{array}{l}\text { 発熱 } \\
\text { 血性鼻漏 } \\
\text { 頓部腫脹 }\end{array}$ & $\begin{array}{l}\text { 約 } 48 \text { } \\
72 \text { 時間 }\end{array}$ & 鼻中隔穿孔 & 側面に傷 \\
\hline $\begin{array}{l}\text { 渡辺ら } \\
(1983)\end{array}$ & 3 歳。7 & 鼻汁漏出 & 約 4.5 時間 & 鼻中隔穿孔 & 陰極面に表面の府食を疑わせる \\
\hline \multirow[t]{3}{*}{$\begin{array}{l}\text { 佐藤ら } \\
(1985)\end{array}$} & 2 歳 & $\begin{array}{l}\text { 右煩部腫脹 } \\
\text { 発熱 }\end{array}$ & 約72時間 & $\begin{array}{l}\text { 鼻中隔架孔 } \\
\text { 前鼻孔閉鎖 }\end{array}$ & 表面軽度腐食 \\
\hline & 2 歳우 & $\begin{array}{l}\text { 左䍡部疼痛 } \\
\text { 左煩部腫脹 }\end{array}$ & 約72時間 & 前鼻子閉鎖 & 肉眼的漏出なし \\
\hline & 5 歳 & $\begin{array}{l}\text { 本頓部腄䐘 } \\
\text { 左鼻閉 }\end{array}$ & 約48時間 & なし & 表面一部わずかに腐食 \\
\hline $\begin{array}{l}\text { 幸田ら } \\
(1986)\end{array}$ & 3 歳す & 左鼻漏 & 約24時間 & 鼻中隔穿孔 & 表面一部腐食 \\
\hline $\begin{array}{l}\text { 自験例 } \\
(1989)\end{array}$ & 3 歳 & $\begin{array}{l}\text { 左血性鼻漏 } \\
\text { 左頖部腫脹 }\end{array}$ & 72 時間以上 & 鼻中隔穿子 & 表面一部腐食 \\
\hline
\end{tabular}

下しているが，これは生理食塩水を入れたビーカーが 開放性であったために大気中の二酸化炭素を吸収した ためであろう。さらに家鬼の鼻腔では二酸化炭素の吸 収と共に体液との中和も考えられる。すなわち，放電 20 日後の生理食塭水の中和に $3.6 \mathrm{ml} \sigma 1$ 規定塩酸を 必要としたが，この量は20日間に生成された $\mathrm{OH}$ 基に 対応するものとは言えない。このように放電により生 成された強アルカリによる組織障害は極めて早期に始 まり，しかも進行性で, 深達性であることが十分理解 されよう，本症例の鼻腔内では電池は固定された状態 にあり，生成された強アルカリは高濃度のまま組織傷 害を起こしたと考えられる。また鼻腔内でも気体の塩 素，水素が発生したと考えられるが，これらの気体が 組織傷害にいかなる関与をしたかについては今後の課 題である，本症例での電撃傷の関与は，電池の電圧が

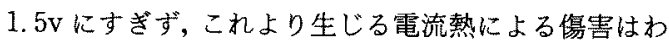
ずかと考える，また電池の压迫による循環傷害は，電 池の鼻腔内介在期間が 4 日以上であったことにより大 いに起こりうるが，これは限局性で患側鼻控にのみと どまると考える，以上のように本症例の重大な組織傷 害は, 主として放電によって生成された強アルカリに よるものであったと考えられ，このように自験例を含 めて, 放電による傷害は急速進行性に生じることが理 解できよう，賃害に対する処置，治㙩には特効的なも
のはなく，頻回の蒸留水による洗浄と感染に対する抗 生物簤の投与程度しかないのが現状である。酸の使用 は中和熱により傷害が助長されるため一般的ではな い゙)とされている。電池の介在時間が短くても，傷害は 重大となりうる，家庭において電池の鼻腔内介在が確 認された場合にとりうる処置としては，まず電池の除 去を試み，鼻部を冷やして，さらに水道水で洗浄し可 及的速やかに耳鼻咽喉科医を受診すべきである。電池 異物による重大な傷害は，鼻腔に限らず食道，胃" 耳道710 でもみられ，その危険性が言われているが，今 後ボタン型電池の使用はますます盛んになり，これに より耳鼻咽喉科領域のボタン型電池の異物症例が増え ることが予想される。最後に，鼻腔異物に限らず，異 物症例一般に抏いて，幼小奣が多く，そのほとんどは 保護者の注意により予防が可能であることを付言して おく.

$$
\text { IV ま と め }
$$

ボタン型電池の鼻腔内異物により重大な組織傷害を 来した一症例を経験したので, 家鬼を用いて局所傷害 モデルを作成し，甥害の発生因子につき検討し，さら に文献的考察を加えて報告した。

1. 症例の鼻腔内傷害は粘膜, 軟骨及び骨の壊死で あり，鼻腔内構造は著しく破壊されていた。 
2. 実験によれば，鼻腔内では短時間に電池の放電 が進み，同時に強アルカリが生成された．これに平行 して鼻腔構造の壊死性変化も進行した。

3. 組織傷害は，主として電池の放電によって生成 された強アルカリによって引き起こされ，これに電撃 傷抽よび压迫による循環傷害も多少関与したと考元 た.

\section{参考文献}

1) Volle E, Beyer P, Kaufmann HJ et al : Therapeutic approach to ingested Button-type batteries. Pediatr Radiol 19:114-118, 1989.

2) 松本和彦：㐭腔異物 (水銀電池) に上る鼻中隔穿孔の1 症例. 耳喉 48:481-483， 1976.

3）幸田純治，木下道子 石田達也：ボタン型アルカリ電

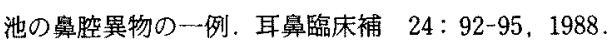

4）渡辺健一郎，内田 豊，宮島逸郎，太田正治：鼻中隔 穿孔をきたした鼻腔異物 (ボタン型電池アルカリ電池) の一症例。耳展 26:171-174, 1983.

5）山下 衛，斉藤重行，小山完二，野口雅之，服部治夫 他：直流低電圧による化学火傷一ボタン型電池の例． 医学のあぬ $126: 957-959,1983$.

6）佐藤洋子，大梘好正，大谷 厳、大内 仁、豊增公一 他：ボタン型アルカリ電池の鼻腔異物の3 症例. 日耳 鼻 $88: 920-925,1988$.

7）近芳久，伊藤俊也，遠藤芳彦，桶口明文，笹森史朗 他：ボタン型電池による外耳道異物症の 1 例. 耳喉頭
缅 62: 441-446. 1990.

8) Fosarelli P, Feigelman S, Peason E et al : An unusual intranasal foreign body. Pediatr Emerg Care 4 (2) : 117-118, 1988 .

9) Hong D, Chu YF et al: Button batteries as foreign bodies in the nasal cavities. Int J Pediatr Otor. hinolaryngol. $14(1): 15-19,1987$.

10) Capo JM, Lucente FE: Alkaline Battery of the ear and nose. Arch Otolaryngol Head Neck Surg $112: 562-563,1986$.

11) Fernando $P$ : Perforation of nasal septum due to button battery lodging in nose. Br Med J Clin Res $294: 742-743,1987$.

12）斉藤宏他: 中毒，黑川利雄他監：現代内科学大 系. 中山畫店, 東京, 1966，158頁．

稿を終えるにあたり，校閲を賜りました日本医科大学 奥田 稔名誉教授に深く感謝致します。また，研究の遂行に あたりご協力戴いた株式会社ソニー・エナジー・テック郡山 工場品質技術部, 品質保証課门皆様, 日本医科大学附属第一 病院病理部竹田数章先生に愿く㧍礼申し上げます.なお゙, 本 論文の要旨は，第93回日本耳鼻咽喉科学会総会において発 表した.

（1992年6月30日受稿 1992年11月5日受理）

別剧請求先 个102 東京都千代田区飯田橋3-5-5

日本医科大学付属第一病院耳鼻咽喉科 大橋晋吾 


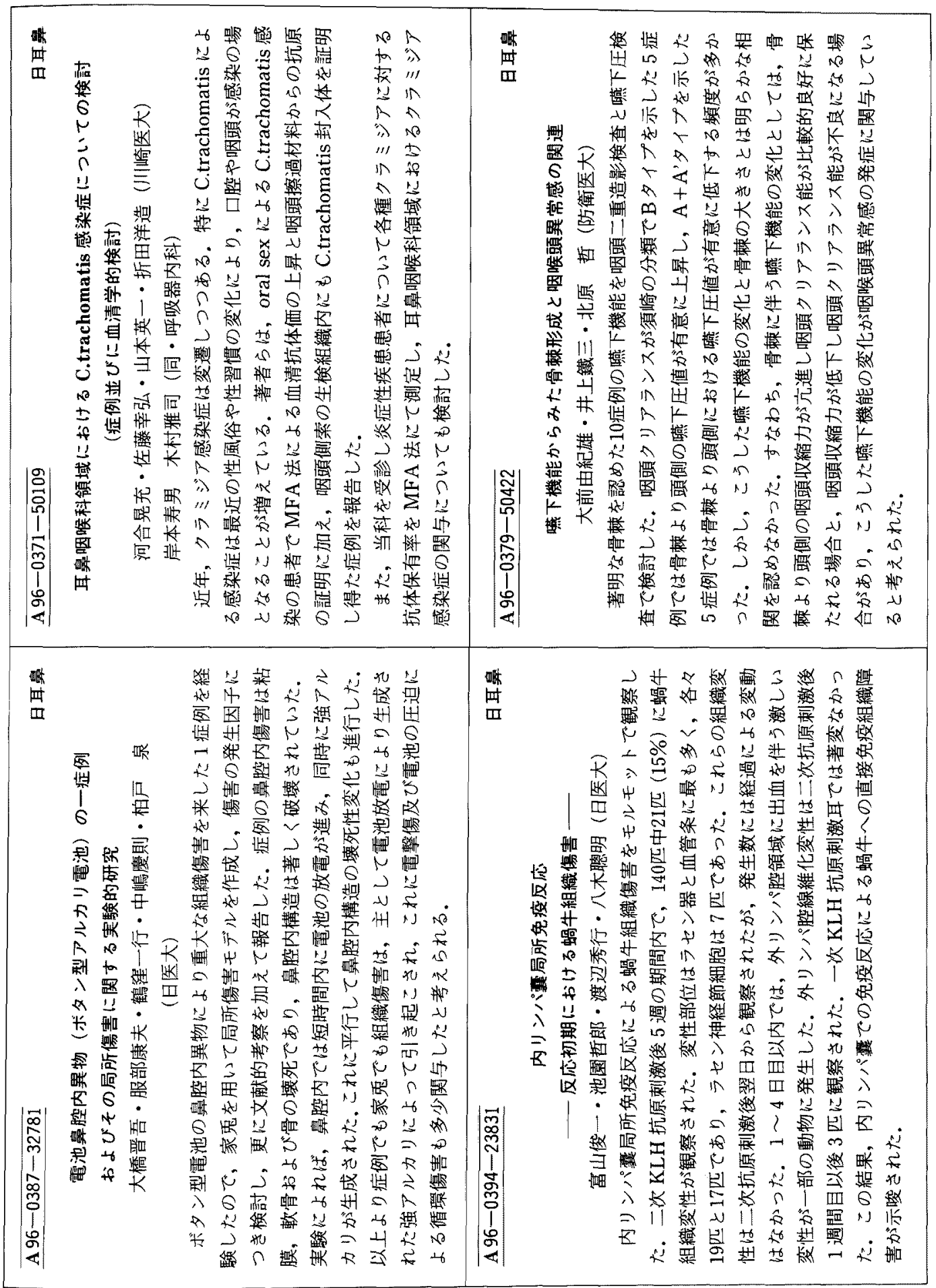

